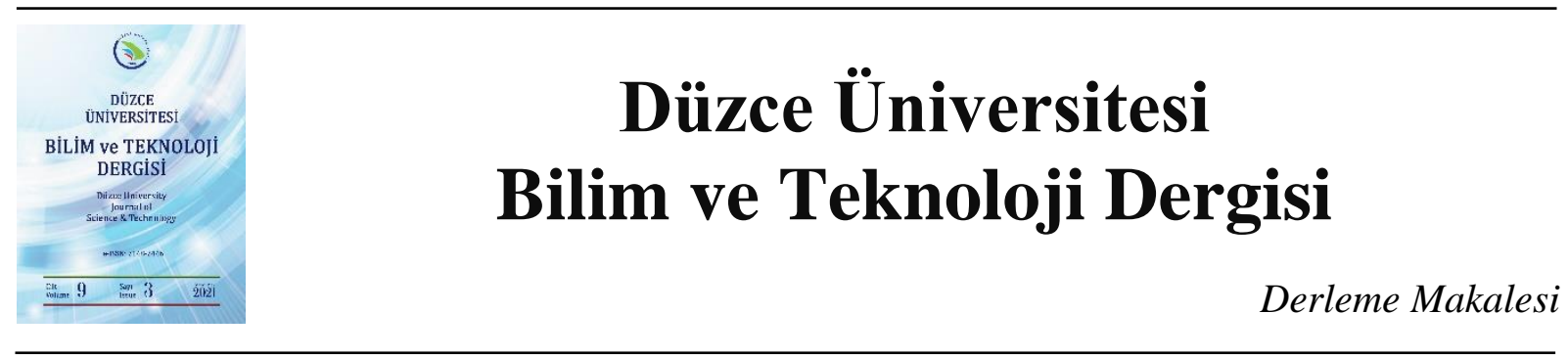

\section{Türkiye'de Yüksek Hızlı Trenlerin Önemi ve Diğer Ulaşım Türleri Arasındaki Tercih Nedenleri}

\author{
(D) Hümeyra BOLAKAR TOSUN ${ }^{\mathrm{a}}$ \\ ä̇nşaat Mühendisliği Bölümü, Mühendislik Fakültesi, Aksaray Üniversitesi, Aksaray, TÜRKIYE \\ * Sorumlu yazarın e-posta adresi:bolakarhumeyra@gmail.com
}

DOI: $10.29130 /$ dubited.873692

\begin{abstract}
ÖZET
Türkiye de ulaşım altyapısı ve ağı kurgularken uzun yıllar demiryolu yatırımları ihmal edilmiştir. Bu durum ulaşım ağı içerisinde türel dağılımı olumsuz etkileyen sonuçlar doğurmuştur. Karayolları ağırlıklı oluşturulan planlamaların çevresel olumsuzlukları ve havayollarının hızlılık avantajına rağmen bu ulaşım türlerinin her noktaya taşımacııık hizmetinin bulunmaması, ulaşım araçlarında yenilikleri beraberinde getirmiştir. Güvenli, hızlı ve konforlu bir seyahat kapsamında geliştirilen yüksek hızlı trenler Türkiye'de yeni bir ulaşım türü olarak karşımıza çıkmaktadır. Ankara, İstanbul, Eskişehir, Konya arasında ulaşıma açılan hatların yanı sıra yapımı devam eden ve yeni oluşturulacak hatlar ile bölgeler ve şehirlerarasında hızlı, güvenli ve konforlu bir seyahat oluşturulması hedeflenmektedir. Bu çalışmada yüksek hızlı trenlerin; güvenlik, konfor, seyahat süresi, ulaşım maliyetleri gibi etkileri incelenmiştir. Mevcut hatlar arasında faaliyet gösteren ulaşım türleri kıyaslamış ve sonuç olarak yüksek hızlı trenlerin birçok etki açısından daha avantajlı ulaşım sağladığı belirlenmiştir.
\end{abstract}

Anahtar Kelimeler: Yüksek hızlı tren, Seyahat güvenliği, Ulaş̧ırma

\section{The Importance of High Speed Trains in Turkey and Reasons for Preference Types of Other Transportation Modes}

\begin{abstract}
Turkey has for many years constructing rail network transport infrastructure and investments were neglected. This situation creates negative effects of trip distribution. Despite the environmental disadvantages of the planning based on highways and the speed advantage of the airlines, the lack of transportation services to every point of these transportation types has brought innovations in transportation vehicles. High-speed railways that developed safe, fast and comfortable travel as a new type of transportation emerges in Turkey. It is aimed that create a fast, safe and comfortable travel between the regions and cities with the on going and newly created lines in addition to the lines opening between Ankara, Istanbul, Eskisehir, Konya. In this study, high-speed trains effects were examined such as safety, comfort, travel, time and transportation costs. Transportation types operating between existing lines have been compared. As a result, it was determined that high speed trains provide more advantageous transportation in terms of many effects.
\end{abstract}

Keywords: High speed train, Travel security, Transportation

Geliş: 03/02/2021, Düzeltme: 12/03/2021, Kabul: 20/03/2021 


\section{GIRIS}

Ulaşım günümüz şartlarında küreselleşme ve ekonomik büyümeye paralel olarak hızlı gelişim göstermektedir. Zamandan tasarruf sağlayan ulaşım sektörü, toplumsal gelişmeye ayak uydurmak zorundadır. Çünkü ulaşım ekonomik, sosyal, siyasal, kültürel ve askeri yapılar gibi birçok yapının temelini oluşturmaktadır. Ayrıca bir hizmet sektörü olan ulaştırmanın istihdam yaratma kapasitesi de oldukça yüksektir. Ulaştırma türleri denizyolu, karayolu, havayolu ve demiryolu olarak dört ana başlik altında incelenir [30].Buna ilaveten boru hatları da bir ulaşım türü olarak görülmektedir. Ulaştırma planlaması yapılırken izlenecek sürecin en önemli aşamasının ileriye dönük olan ulaşım talebinin tahmin edilmesi ve bu talebin ulaştırma türlerine göre nasıl dağıtılacağının hesaplanması olduğunu göz önünde bulundurmak gerekir.

Demiryolu ulaşımının, kara ulaştırması türleri arasında birim hacmine göre enerji tüketimi, arazi kullanımı, çevresel etki ve ekonomiklik bakımından en iyi ulaşım türü olduğu, ve ayrıca enerji tüketimi, çevresel etki ve parasal verimlilik bakımından havayolu ulaştırmasına göre de üstün olduğu kabul edilmektedir. Türlerin teknolojik gelişmelerle entegrasyonu sonucunda değişimi ve gelişimi, yük ve yolcu taşımacılığında türler arası tercihte belirleyici bir rol oynamaktadır. Hız, güvenlik, sistematiklik, konfor, seyahat süresi, taşıma kapasitesi, maliyet ve çevre uyumu gibi nitelikleri daha iyi karşılayan ulaşım türleri daha çok tercih edilmektedir [1-2].

Osmanlı İmparatorluğundan devralınan ve yabancı şirketlerin imtiyazında bulunan demiryolunun 3.714 km'si ana hat, 845 km'si tali hat olmak üzere toplam 4559 km'lik kısmı Kurtuluş Savaşından sonra devletleştirilmiştir. 1932 yılında 1. Beş Yıllık Sanayi Planında ve özellikle 1936 yılında hazırlanan 2. Beş Yıllık Sanayileşme Planında Türkiye gerek yolcu ulaşımı sorununu çözmek ve gerekse oluşumuna ağırlık verdiği demir-çelik, kömür ve makina gibi temel sanayi girdilerinin hacimli ve yoğun yüklerini demiryolları ile en ucuz biçimde taşımak amacıyla bilinçli bir demiryolu politikası izlemiştir [23]. Türkiye kuruluşundan itibaren 1950 yılına kadar demiryolları üzerinde çalışmalar gerçekleştirirken 1950'den 2009'a kadar gereken önem verilmemiştir. Böylece kara-hava-demir yolu ulaşımları arasında dengesiz bir dağılım oluşmuş̧tur. 2009 yılında işletime açılan ilk yüksek hızlı tren seferleri ile demiryollarına verilen önem yeniden artmıştır [7-9]. Türkiye'de ulaşım konusunda daha çok karayolu ağırlıklı ulaşım tercih edilirken hız, maliyet, güvenlik ve sürdürülebilir ulaşım açısından yüksek hızlı trenlerin diğer türlere oranla daha etkin olması, ulaşım türleri arasındaki payını giderek arttırmaktadır [4]. Yüksek hızlı trenleri daha çok yolcu taşımacılığında kullanılmakta [3] ve hareketliliğin karşılanmasında önemli bir alternatif oluşturmaktadır [6]. Yüksek Hızlı Trenler, ihtiyaç duyulan alt yapının sağlanmasında ilave yatırım maliyetleri gerektirse de karayollarına göre daha hızlı ve güvenli, havayollarından daha ucuz olması ve daha düşük enerji ile seyahat imkânı sağlamasıyla tercih edilebilirliğini arttırmıştır [5].

Stoop ve Thissen [15] çalışmalarında, yüksek hızlı demiryollarının yaygınlaşmasında güvenliğin önemli bir etken olduğunu ifade etmişlerdir. Şahin ve Altan [8] çalışmalarında, YHT(Yüksek Hızlı Tren) planlamasında etkili olan güvenlik için hem işletme maliyeti hem de yolculuk süresindeki kayıpları önleyecek programlama modeli geliştirmişlerdir. Albalate vd. [9], hava yolu ve demir yolu arasındaki rekabete ek olarak yüksek hızlı demiryollarının hava yolu taşımacılığı için intermodal (taşıma kabı değiştirilmeden en az iki farklı taşımacılık modu kullanılarak yapılan taşıma şekli) bir taşıma olduğunu belirtmiş̧ir. İnan ve Demir [6], yüksek hızlı demiryollarının çevre dostu, enerji tasarrufu sağlaması ve ekonomikliğinin yanı sıra karayollarına göre arazi kullanımında da avantajlı olduğunu belirtmiştir. Dalkılıç ve Yaman [12], yüksek hızlı trenlerin düşük maliyetli olmasından dolayı tercih edilebilirliğini arttırdığını belirlemişlerdir. Sarı vd. [14] çalışmalarında, yüksek hızlı tren hizmet kalitesinin belirlenmesinde zaman tasarrufu sağlamasından dolayı yolcu tercihleri üzerinde etkili olduğunu belirtmişlerdir. Borras vd. [16] yaptıkları çalışmada, yüksek hızlı trenlerin çevre dostu bir ulaşım sağlaması ve seyahat ücretlerinin uygun aralıklarda fiyatlandırılmasından dolayı yaygın bir ulaşım türü haline geldiğini belirtmişlerdir. Ayrıca ulaşım sisteminin altyapı inşa maliyetlerinin yüksek oluşu, kademeli yatırımın mümkün olmayışı, sistemin ancak ve ancak arazinin belirlenen eğimlerde olması koşuluyla çalışabilir olması, demiryolu ulaştırma ağı tesis etmede coğrafi 
engellerden kaynaklanan çeşitli kısıtların olması sistemin dezavantajları olarak karşımıza çıkmaktadır [21].

\section{MATERYAL VE YÖNTEM}

Türkiye'de ilk hızlı demiryolu araçları, yolcu taşımacılığında yaklaşık 2 saat 40 dakika seyahat süresi ile 2009'da Ankara-Eskişehir hattının işletime açılmasıyla başlamıştır. 2011 yılında Ankara-Konya, 2014 yılında Ankara-Pendik (İstanbul) ve Konya-Pendik, 2019 y1lında Ankara-Halkalı (İstanbul) ve Konya-Halkalı hatlarında yolcu taşıma hizmetleri verilmeye başlamıştır [10].

\section{A. TERCIHİ ETKILEYEN PARAMETRELER}

Yüksek hızlı trenlerin geleneksel demiryolu araçlarından farklı özelliklere sahip olması diğer ulaştırma türleri ile rekabetini arttırmaktadır. Demografik özellikler, hareketlilik, seyahat süresi, erişilebilirlik ve maliyet diğer türler ile rekabetinde belirleyici unsurlardır [9,20]. İklim koşullarından etkilenmemesi ve akıllı ulaşım sistemlerinden faydalanılarak oluşturulan sistemler sayesinde yüksek hızlı trenler güvenli, konforlu ve rahat bir ulaşım sağlar. Arazi kullanımında küçük bir pay ile taşıma sağlayan demiryolları düşük maliyetli yatırımların oluşturulmasını ve arazi tasarrufunu sağlamaktadır [6]. Yüksek hız ve yüksek taşıma kapasitesine sahip olması kara yolu trafiğini ve buna bağlı oluşan tıkanıklıkların önüne geçmek için alternatif bir ulaşım aracıdır. Diğer türelere göre seyahat süresinde ve yakıt maliyetlerinde avantaj sağlamaktadır [9].

\section{A.1. Çevre Duyarlılığı}

$\% 100$ elektrikli bir sistem olan yüksek hızlı trenler, daha ileri teknolojik gelişmelere ihtiyaç duymadan yenilenebilir enerji ile uyumludur. Günümüzde YHT, şehirlerarası ve uzun mesafeli taşımacilıkta önemli oranda yenilenebilir enerji tüketen tek ulaşım türüdür.Çekiş için kullanılan yenilenebilir kaynaklardan elde edilen elektrik miktarı arttıkça, $\mathrm{CO}_{2}$ gaz emisyonları da düşmektedir. Elektrikle çalışmanın avantajlarından biri, diğer ulaşım türlerinin tam tersine, yüksek hızlı teşebbüslerin ana yenilenebilir enerji formlarını kolayca kullanabilmesidir. Bu bağlamda, bazı demiryolu şirketleri yenilenebilir elektrik paylarını arttırmayı amaçlamışlardır. Örneğin, İskandinavya, İsviçre ve Avusturya'da elektrikle çalışan demiryolu ağları vardır. Benzer şekilde, Hollanda demiryolları, tüm enerji gereksinimlerini yeni inşa edilen yenilenebilir enerji kaynaklarından satın almak için bir sözleşme imzalamıştır. Ülkemizde de ulaştırma türlerinin doğa üzerinde oluşturduğu olumsuzluklardan dolayı yeni politikalar belirlenmiş ve bu zararları giderecek yeni yöntemler geliştirilmiştir [22]. Bu çevresel etkileri minimize etmek için kullanılan yöntemlerden biride tamamen elektrikle çalışan yüksek hızlı trenlerdir [10-15].

Karbon salınımı açısından yüksek hızlı trenler diğer türler ile kıyaslandığında, 1 kg karbondioksit salınımının oluşması için elektrikli demiryolu araçlarında $42 \mathrm{~km}$, otobüs ve otomobil ile sırasıyla 12 ve $7 \mathrm{~km}$, havayollarında ise $7 \mathrm{~km}$ 'lik yol kat edilmektedir [19]. Yenilenebilir enerji kaynakları kullandığı için karbon emisyon salınımları sıfıra yakın değerlerde olduğundan YHT'lerin çevreye verdiği zarar diğer ulaştırma türlerine göre daha azdır ve düşük enerji tüketimi ile yolcu taşıma hizmeti sunmaktadırlar [6,11].

Şekil 1.'de Havayolu, karayolu ve demiryolu ile gidilen 600 km'lik bir yol için tüketilen yakıt (Litre) ve $\mathrm{CO}_{2}$ emisyonu (kg) karşılaştırılmıştır. 


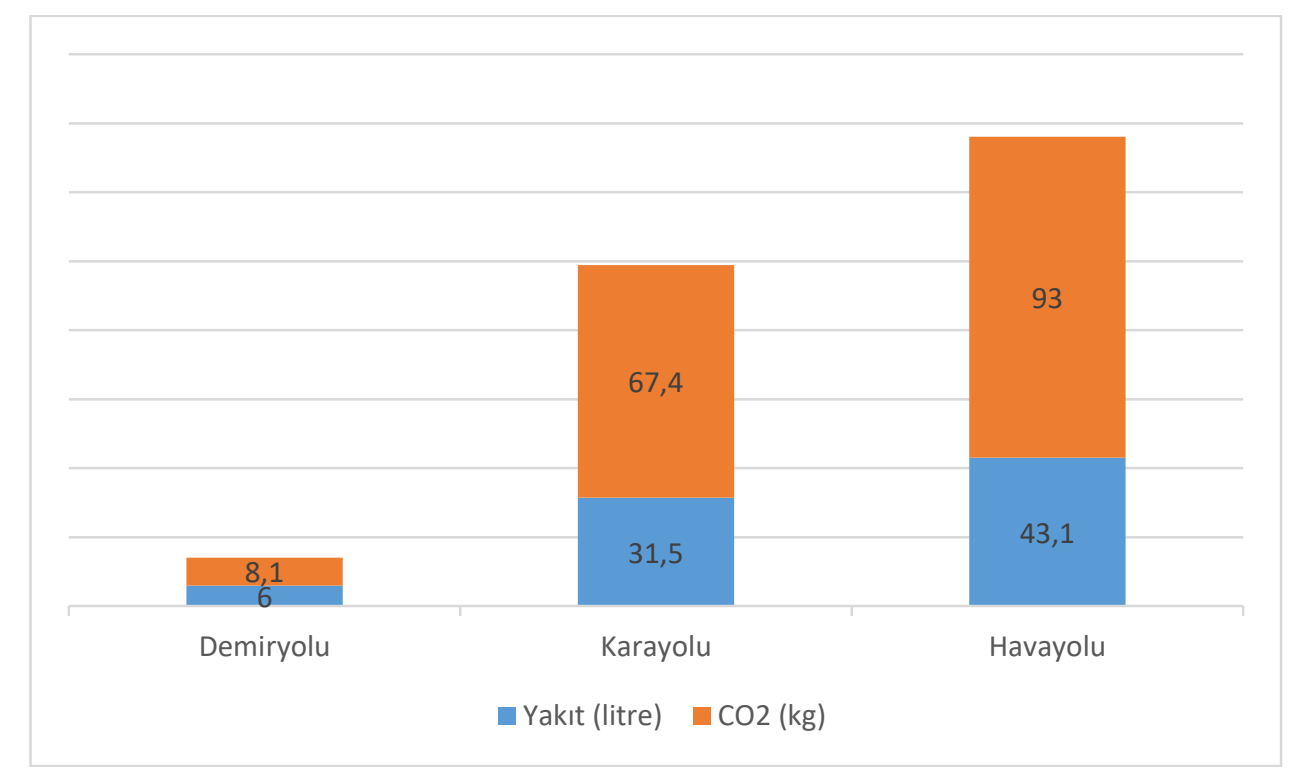

Şekil 1.600 km'lik bir yol için yakıt tüketimi (Litre) ve CO2 emisyonu (kg) karşılaştırılması [6].

\section{A.2. Güvenlik}

Yüksek hızlı trenler, hızlı ve güvenli bir taşımacılık hizmetini sağlamak için tasarlanmış ve üretilmiştir [21]. Bu tür araçlarının belirlenen hızlara erişebilmesi için uygun altyapı ve özel tasarımların oluşturulması gerekir. Bunun için yüksek hızlarda kurp geçişleri ve istasyonlar arası durkalk noktalarında güvenli bir yolculuk için sinyalizasyon sistemlerinden yararlanılır. Böylece yüksek hızlarda seyahat imkânı sağlamasının yanı sıra kaza oranları diğer türlere göre daha azdır ve emniyetli bir seyahat hizmeti sunmaktadır [11,17]. Bu sebeplerden dolayı güvenlik unsuru da yüksek hızlı trenlerin tercih edilme sebepleri arasındadır. Dünya üzerinden kaza örnekleri arasında yer alan, Japon Tokaido Shinkansen hattında 30 yıl içinde 3.5 milyar yolcu taşınmıştır. Ölümlü ya da yaralanmalı hiçbir kaza olmamıştır. Türkiye'de 2007-2012 yılları arasında toplamda 242,3 milyon tren.km taşımacılık yapılmış ve 503 kişi demiryolu kazası nedeni ile hayatını kaybetmiştir [24, 25]. 2007-2012 yılları için toplamda Türkiye için milyon tren.km başına ölüm miktarı 2,08 olarak hesaplanmıştır. Tablo 1'de 2008-2012 y1lları için Avrupa Birliği, ABD, Kanada, G.Kore, Avusturalya ve Türkiye'nin değerleri görülmektedir [26]. En düşük oran 0,16 değeri ile Avusturalya, 0,32 değeri ile Avrupa Birliğine aittir. Türkiye haricindeki ülkeler için ortalama değer 0,43 dür. Türkiye'de 48 Demiryolu Mühendisliği 2008-2012 yılları toplamı için dünya ortalamasının yaklaşık beş katı ölüm vakası meydana geldiği anlaşılmaktadır.

Tablo 1. Dünyada ve Türkiye'de 2008-2012 arasındaki yıllar için milyon tren km olarak ölüm miktarları

\begin{tabular}{cccccc}
\hline AB & ABD & Kanada & G.Kore & Avustralya & Türkiye \\
\hline 0,32 & 0,63 & 0,6 & 0,45 & 0,16 & 2,08
\end{tabular}

\section{A.3. Maliyet}

Yüksek hızlı trenler; kılavuz raylar, istasyonlar, enerji tedariki, demiryolu araçları ve sinyalizasyon sistemlerinden oluşmaktadır [13]. Ayrıca bu araçlar büyük oranda yolcu taşıma kapasitesine sahiptir. Yatırım maliyetleri yüksek olmasına rağmen birim enerji miktarıyla daha fazla yolcu taşıdığı için kullanılan yakıt maliyeti düşük, enerji verimliliği yüksektir $[6,18]$. 


\section{A.4. Seyahat Süresi}

Yüksek hızlı trenler ile yolcu taşımacılığı Türkiye'de yeni bir ulaşım hizmeti sunarken seyahat süresindeki avantajlar sayesinde havayolu ve karayolu ile rekabet edebilecek bir düzeye ulaşmıștır [12]. Seyahat suresi ulaşım türleri arasında tercih edilebilirlik açısından oldukça önemli bir parametredir. Türkiye'de yolcu taşımacılığı yapan hatlar ile Ankara-Eskişehir hattı yaklaşık 1 saat 30 dk, Ankara-Konya ortalama 1 saat 50 dk; Ankara-Pendik ortalama 4 saat; Konya-Pendik 4 saat 20 dk; Ankara-Halkalı 5 saat $30 \mathrm{dk}$; Konya-Halkalı 5 saat 40 dakikalık seyahat süresi ile ulaşım sağlamaktadır. Ve bu süreler sayesinde bahsedilen illerdeki ulaşım tercihlerinde diğer türlere oranla demiryolu taşımacılığında artış gözlenmiştir.

\section{A.5. Hiz ve Konfor}

Yüksek hızlı trenlerin uzun mesafeli yolcu taşımacılıklarında havayolları ile rekabete girebileceği görüşü ağırlık kazanmıştır. Gürültü ve titreşim gibi faktörler yüksek hızlı trenlerin yoğun olarak kullanıldığ1 Japonya'da sorunlara sebep olmuştur. Aynı sorunların Almanya'da da dile getirilmesi neticesinde yüksek hızlı trenlerin azami hızlarına sınırlama getirilmiştir. Daha yüksek hızlara ancak gürültü düzeylerinde azalmalara gidildiği takdirde izin verileceği Almanya ve İngiltere hükümetleri tarafindan dile getirilmiştir. Son yıllarda araştırma-geliştirme çalışmaları sonucunda hızlı trenlerin gürültü düzeylerinde ciddi azalmalar gerçekleşmiştir. $300 \mathrm{~km} / \mathrm{s}$ hıza ulaşan Atlantik hızlı trenlerinin gürültü değeri bir önceki kuşak olan güneydoğu hızlı trenlerinin $270 \mathrm{~km} / \mathrm{s}$ hıza ulaştıklarında çıkardıkları gürültüden daha düşüktür [23]. Yüksek hızlı trenler, karayollarına göre daha kısa seyahat süresiyle yolculuk imkanı sunmaktadır ve bu da tercih edilebilirlik açısından en önemli etkendir. Güvenlik ve gürültü kaynaklı rahatsızlıkları önlemek açısından hatların geçtiği kalabalık nüfuslu yerlerde, tünel ve köprülerde hız sınırlandırılmaktadır. Hız değerleri arttıkça altyapı maliyetleri de hızla birlikte doğrusal olarak artmaktadır. Bu yüzden yüksek hız için güvenli, emniyetli ve esnek bir altyapının oluşturulması da gerekmektedir [21]. Türkiye'de faaliyette olan yüksek hızlı trenler 250 $\mathrm{km} / \mathrm{sa}$ hızlara erişerek seyahat hizmeti sunmaktadır. Bu araçlar gürültü, ses ve 1sıya karşı gerekli yalıtımların oluşturulması ile konforlu bir hizmet sağlamaktadır. Ayrıca hava koşullarından etkilemediği için sürekli ulaşım hizmeti de sunmaktadır [11].

\section{A.6. Dakiklik ve Erişilebilirlik}

Ulaşım türlerinde dakiklik ve hizmetlerdeki süreklilik tür tercihinde etkilidir [15]. Yüksek hızlı tren hatlarının bölgelere en temel ve doğrudan etkilerinden bir tanesi, bölgedeki bir alanın veya bir şehrin ekonomik coğrafi konumunu değiştirmesidir. Ana ulaşım güzergâhları merkezinde olmayan bir bölge, hızlı tren hatlarının varlığıyla konum avantajını değiştirebilmektedir. Bölgelerin, şehirlerin ve alanların gelişimini teşvik etmek ve bölgesel kalkınmayı daha da desteklemek için yüksek hızlı tren hatları önem kazanmıştır. Merkez şehirlerin ve istasyonlu şehirlerin erişilebilirliğinin geliştirilmesi, bu merkezlerin çevre bölgelerden daha büyük olmasını sağlamıştır. Aynı zamanda kentlerin büyümenin getirdiği olanaklardan daha fazla yararlanmasını da sağlamıştır [23]. Seyahat süresinde varış-kalkış noktaları, istasyonlar arasında dur-kalk süreleri programlı olarak düzenlendiği ve akıllı ulaşım sistemlerinden faydalanarak herhangi bir gecikmeyi güzergah üzerinde engelleyebildiği için yüksek hızlı trenler dakik bir ulaşım sistemidir. Yüksek hızlı trenlerin erişilebilirlik açısından geçtiği güzergâhlar üzerinde bulunan yerleşmeler gelişmeye başlamış ve şehirlerarası etkileşimlerde artmıştır [17]. Ayrıca terminallere ulaşım konusunda rahatlık sağlayan tren istasyonları, genellikle havayollarına göre şehir merkezlerine yakın mesafede konuşlandırılmıştır. Böylece yüksek hızlı trenlere ait terminallere erişimde kolaylık sağlanmıştır. 


\section{BULGULAR VE TARTIȘMA}

Türkiye'de ulaşım türleri arasında taşınan yolcu ve yük miktarlarının yüzdelik payları 2015 yılı itibari ile Tablo 2'de verilmiştir [27].

Tablo 2.: Türkiye'de ulaşım türleri arasında taşınan yolcu ve yük payları (\%) (2015)

\begin{tabular}{ccc}
\hline Ulaşım Türüi & Yolcu Taşıma Payı & Yük Taşıma Payı \\
& $\%$ & $\%$ \\
\hline Karayolu & 89.8 & 89.5 \\
\hline Demiryolu & 1.1 & 4.6 \\
\hline Denizyolu & 0.6 & 5.4 \\
\hline Havayolu & 8.5 & 0.4 \\
\hline Boru Hatları & - & 11.5 \\
\hline
\end{tabular}

\section{A. KARAYOLARI ÍLE ULAŞIM}

Uzun yıllar karayolları ağırlıklı yatırımlar türler arası dengesizliklere ve tek bir türe bağlı taşımacılığın gelişmesine neden olmuştur. Enerji kaynaklarında dışa bağlı olması ve çevresel tahribatlara yol açmasının yanı sıra yetersiz kapasiteye bağlı tıkanıklıkların yaşanması, trafik kazalarındaki artış, yol bakım-onarım maliyetlerinin yüksek olması maddi-manevi kayıpları da beraberinde getirmiştir. Raylı sistemlerin taşıma kapasitesi tek seferde karayolları ile taşınan yolcu kapasitesine göre çok daha fazladır. Karayolu araçlarının oluşturduğu trafik, yüksek enerji maliyetleri, çevresel zararlar, trafik kazalarından kaynaklı yaralanma ve ölümlerden dolayı demiryolları sağladığı avantajlardan dolayı karayollarının yerini almaya başlamıştır [18].

Aynı kapasitede yolcu taşıma değerleri için demiryollarında 13,7 m genişlikte bir platform yeterliyken, karayolları için bu platform genişliği 37,5 metredir. [19]. Demiryolları, karayollarına göre daha uygun maliyetli ve çevresel etkileri daha azdır. Her noktaya ulaşım sağlaması, sık sefer imkânı sunması bir avantaj gibi görülürken enerjide dışa bağlı olması ekonomide olumsuz etkiler yaratmaktadır [11].

\section{B. HAVAYOLLARI İLE ULAŞIM}

Hava yolu ile ulaşım hizmetlerinde seyahat süresi kısadır. Hızlı ve güvenli seyahat imkânı sağlamaktadır. Ancak taşıma maliyeti yüksektir. İklim koşullarından etkilendiği için rötarlara ya da seferlerde değişikliklere neden olmaktadır. Ayrıca her bölgeye havayolları ile ulaşım mümkün değildir [22]. Yüksek hızlı tren ve hava yolu arasındaki rekabet dünyanın her yerinde ve günün her anında birçok yerde defalarca incelenmiştir. Demiryoluyla yapılan yolculuklarda seyahat süresinin 2 saatten az olduğu durumlarda, YHT tamamen piyasaya hâkimdir ve hava şirketleri siklıkla rekabet etmekten vazgeçerler. Demiryoluyla yapılan yolculukların seyahat süresi 2 saat ile 3.5 saat arasında olduğunda, demiryolu hakim taşımacılıktır. Demiryolunun seyahat süresi 3.5 saat ve 5 saat arasında olduğunda, havayolu ile ulaşım demiryoluna göre daha baskın taşımacılıktır. Tabii ki, bu trafik bölünmesi, istasyonların ve havaalanlarının yerleri, bilet fiyatları ve servis sıklığ gibi diğer parametrelerden etkilenebilir. Bununla birlikte, UIC (International union of railways) tarafindan yapılan son Avrupa araştırmalarının sonuçları incelendiğinde düşük maliyetli hava şirketleri ve tam paket satan tur operatörleri düşünüldüğünde bile demiryolu her zaman havayolundan daha ucuz bir taşımacıllk hizmeti sunmaktadır.

Havayolları yakın mesafelerde ulaşım sağlamadığı için yüksek hızlı trenlerin bulunduğu bölgelerin bazılarında havayolları ile seyahat imkânı yoktur. Bu yüzden yüksek hızlı trenler yakın ve uzak mesafeli noktalar arasında seyahat hizmeti sağladığı için havayollarına göre avantajlı bir ulaşım türüdür. İki tür içinde hız parametreleri ortak bir etken olmasına rağmen havayollarında seyahat ücreti, 
seyahat tarihine kadar fiyatlarda yaşanan değişkenlikler açısından yüksek hızlı trenler daha uygun maliyetlerle seyahat hizmeti sağlamaktadır.

\section{YÜKSEK HIZLI TRENLER İLE ULAȘIM}

Yüksek Hızlı Tren Hatları üzerinde taşınan yolcu sayısı dikkate alındığında her yıl bir önceki yıla göre taşınan yolcu sayısı artış göstermiştir. 2016 yılında toplam 5.899 yolcu seyahat için yüksek hızlı demiryollarını kullanırken yaklaşık \% 40 artışla 2019 yılında 8.274 yolcu yüksek hızlı trenler ile seyahat etmiştir. Ayrıca yüksek hızlı trenler, komşu illere de kombine taşımacılık imkânı sağlamaktadır. Ankara-Eskişehir hattında YHT hizmeti başlamadan önce demiryolu taşıma payı \% 8 iken hattın işletime açılmasıyla demiryollarının payı \% 72'ye ulaşmıştır. Konya-Ankara arasında YHT hizmetinin payı \% 66 'ya ulaşmıştır [10].

Tablo 3. Yüksek hızlı demiryollarının kullanan yolcu sayısı (bin kişi)[10].

\begin{tabular}{ccccc}
\hline YHT Güzergâhı & $\mathbf{2 0 1 6}$ & $\mathbf{2 0 1 7}$ & $\mathbf{2 0 1 8}$ & $\mathbf{2 0 1 9}$ \\
\hline Ankara-Eskişehir & 1.237 & 1.339 & 1.426 & 1.509 \\
\hline Ankara-Konya & 1.775 & 2.047 & 2.243 & 2.099 \\
\hline Ankara-İstanbul & 2.203 & 2.873 & 3.269 & 3.418 \\
\hline Konya-İstanbul & 684 & 905 & 1.167 & 1.248 \\
\hline
\end{tabular}

Hızlı trenler, kullanım kolaylığı, fiyat avantajı, emniyetli ve hızlı olmasıyla farkını ortaya koyar. Otomobilinizle gideceğiniz bir yolu hızlı trenle daha kısa sürede, daha emniyetli ve elbette daha ucuza ulaşma imkanı sağlar. Hızlı trenler tüm ülkelerdeki otoyol hız limitlerinden çok daha yüksek hızda seyahat yapma firsatı verir. Genel olarak yolculuk mesafesi arttıkça hızlı trenin otoyola olan zaman avantajı artar. Yolculuk boyunca özgür alanlar sunar. Elektrik enerjisi ile çalışan hızlı trenler, çevreye zarar vermediği gibi diğer ulaşım araçlarına göre sessiz çalışarak gürültü kirliliği de üretmezler.

\section{DENIZYOLLARIILE ULAŞIM}

Denizyolu ulaşımında ekonomi, çevre, sosyal ve güvenlik konuları ön plana çıkmaktadır. Denizyolu ulaşımı, Avrupa anakarasında üretilen ürünlerin dünyaya taşınması hususunda çok boyutlu olarak karşımıza çıkmaktadır.

Diğer ulaşım modlarında yakalanan ivmelerin sonucunda alternatif yakıt kullanımı ve çevresel zararların azaltılması (sera gazları, gürültü, atıklar, kirleticiler) konularında ilerlemeler kaydedilmesi ihtiyacı ortaya çıkmıştır. Bu ihtiyacın ortaya çıkmasında denizyolu ulaşımının diğer ulaşım modalarının (havayolu, demiryolu ve karayolu) gerisine düşmeye başladığı fark edilmesi ile tercih edilebilirlikte önemli bir etken olmuştur.

\section{IV.SONUC}

Yüksek hızlı trenler Türkiye'de on bir yıldır faaliyet göstermektedir. Sağladığ 1 avantajlar ile diğer türler arasında bir rekabet ortamının oluşmasının yanı sıra kombine taşımacılık için de önemli katkılar sağlamaktadır.

Çevresel duyarlılık açısından karayolları ve havayollarının gaz emisyon değerlerinin yüksek hızlı trenlere göredaha yüksek olması sebebiyle, yüksek hızlı trenler şehirlerarası ulaşımda daha fazla tercih edilmektedir. Ayrıca diğer türlerin dışa bağımlı ve yenilenemez enerji kaynakları kullanmasının yanında yüksek hızlı trenlerin yenilenebilir enerji kaynaklarından faydalanması sürdürülebilir ulaşım kavramıyla örtüşmektedir. Karayolları taşımacılı̆̆ında meydana gelen kazalarda ölüm ve yaralanma olayları oldukça fazladır. Yüksek hızlı trenler, kullanılan akıllı ulaşım sistemleri sayesinde güvenli taşımacılık hizmeti sağlamaktadır. 
Karayolları ve yüksek hızlı trenler altyapı ve işletme maliyetleri kıyaslandığında yüksek hızlı trenlerin altyapı maliyetleri yüksek olmasına rağmen işletme maliyetleri karayollarına göre daha uygundur. Seyahat süresi yüksek hızlı trenlerin geçtiği bölgeler ile kıyaslandığında ve terminallere ulaşım süresinden varış noktasına kadar geçen süre değerlendirildiğinde yüksek hızlı trenler, havayolları ve karayollarına göre daha kısa sürede ulaşım sağlamaktadır. Ayrıca havayolları yüksek hızlı trenlerin eriştiği bazı bölgelere seyahat hizmeti sunmamaktadır.

Havayolları ve demiryolları, karayollarına göre daha hızlı ulaşım sağlamaktadır. Havayolları ve karayolları taşımacılığı iklim koşullarından etkilendiği için olumsuz hava şartlarında süreklilik sağlamamaktadır. Ayrıca hava limanları yerleşkesi şehir merkezinden uzak bir noktada kurulduğu için erişim zordur. Yüksek hızlı trenler akıllı ulaşım sistemleri sayesinde dakik bir ulaşım sistemidir ve hava koşullarından etkilenmemektedir. Genel olarak elde edinilen bilgiler ışığında yüksek hızlı trenlerin tercih edilme nedenleri;

- Hem uzun hem de kısa mesafelerde hızlı nakliyat sağlaması,

- Demir tekerlek ile demir yol arasındaki sürtünmenin az oluşu nedeniyle birimnakliyat başına enerji tüketiminin diğer sistemlere nazaran düşük olması,

- Ulaşımda trafik sorunu olmamasi,

- Güvenli konforlu ve hızlı seyahat imkânı sağlaması,

- Diğer ulaşım türlerine nispeten daha çevreci olması,

- Hava koşullarından etkilenmemesi,

- Kolay erişim, sürdürülebilirlik, memnuniyet ve çekicilik parametrelerine sahip olması,

- Servis sıklığı, düzenli tren aralıkları gibi parametrelerin uygulanabilirliği,

- Yüksek düzeyde konfor,

- Diğer ulaştırma türleriyle uygunluk,

- Tren içinde ve istasyonda sunulan servisler,

- Diğer ulaşım türlerine oranla yapım aşamasında daha az arazi kullanımı gereksinimi,

olarak siralanabilir.

\section{KAYNAKLAR}

[1] A. Erel, "Ulaştırma planlamasında talep-sunu ilişkileri," 3. Ulaştırma Kongresi Bildiriler Kitabl, 1995, ss. 81-92.

[2] A. Vassilios, "Railway," Management and Engineering, c. 3, 2006.

[3] İ. Pektaş, "Raylı ulaşım sistemleri sektör analizi," Anadolu Raylı Ulaşım Sistemleri Kümelenmesi, ss. 12-17, 2017.

[4] Z. Öztürk, "Yüksek hızlı demiryollarının gelişimi ve Türkiye'nin durumu," 2. Ulaşım ve Trafik Kongresi-Sergisi, Ankara, Türkiye, 1990, ss. 309-317.

[5] Başbakanlık Hazine Müsteşarlığı "Dünya'da ve Türkiye'de yüksek hızlı tren işletmeciliği raporu," Türkiye, Rap. T.C.: 1-17, 2015.

[6] M. İnan ve M. Demir, "Demiryolu ulaşımı ve Türkiye'de hızlı tren yatırımlarının etkileri: Eskişehir-Konya örneği," Firat Üniversitesi Sosyal Bilimler Dergisi, c. 1, ss. 99-120, 2017.

[7] Türkiye Cumhuriyeti Devlet Demiryolları (TCDD) Taşımacılık, "2017 Faliyet Raporu," Türkiye, Rap. TCDD: 29, 2017. 
[8] O. Şahin ve M. F. Altan, "İnvestigating high speed railways in terms of the economy for our country and the region," Journal of Sustainable Construction Materials and Technologies, c. 3, s. 1, ss. $156-162,2018$.

[9] D. Albalate, G. Bel ve X. Fageda, "Competition and coorperation between high-speed rail and air transportation services in Europe," Journal of Transport Geography, s. 42, ss. 166-174, 2015.

[10] Türkiye Cumhuriyeti Devlet Demiryolları (TCDD) Taşımacılık, "2019 Faliyet Raporu," Türkiye, Rap. TCDD: 29, 2019.

[11] S. Murat ve L. Şahin, "Dünden Bugüne İstanbul'da Ulaşım,” İstanbul Ticaret Odası, Yayın 201-58, ss. 53-56, 2010.

[12] G. Dalk1liç ve H. T. Yaman, "Evaluation of The pricing preferences and value of time for high speed rail users in the Turkey," Journal of the Faculty of Engineering and Architecture of Gazi University, c. 34, s. 1, ss. 255-273, 2019.

[13] G. De Rus, I. Barron, J. Campos, P. Gagnepain, C. Nash, A. Ulied ve R. Vickerman, "Economic analysis of high speed rail in Europe," Fundacion BBVA, ss. 36-38, 2009.

[14] Y. Sarı, A. Kılıçlar ve C. Seçilmiş, "Yüksek hızlı tren yolcularının kişisel değişkenler açısından memnuniyet algılamalarının değerlendirilmesi," Anatolia: Turizm Araştırma Dergisi, c. 22, s. 2, ss. 127-138, 2011.

[15] J. A. Stoop ve W. A. H. Thissen, "Transport safety: trends and challenges from a systems perspective," Safety Science, c. 26, s. 1/2, ss. 107-120, 1997.

[16] M. S. Borras, C. Nash, P. Abrantes ve A. L. Pita, "Rail access charges and the competitives of high speed trains," Transport Policy, c. 17, s. 2, ss. 102-109, 2010.

[17] M. Garmendia, C. Ribalaygua ve J. M. Urena, "High speed rail: implication for cities," Cities , c. 29 , ss. $26-31,2012$.

[18] A. Y. Gündüz, M. Kaya ve C. Aydemir, " Kent içi ulaşımda kara yolu ulaşımına alternatif sistem: raylı ulaşım sistemi," Akademik Yaklaşımlar Dergisi, c. 12, s. 1, ss. 134-151, 2011.

[19] High speedrail, "Fast track to sustainable mobility" [Online]. Erişim: http://www1.mmo.org.tr/resimler/ekler/b7e926154c1274e_ek.pdf

[20] R. Vickerman, "High speed rail in Europe: experience and issues for future development," The Annals of Regional Science, c. 31, ss. 21-38, 1997.

[21] International Union of Railways, [Online]. Erişim: http://www.uic.org.tr/passenger/highspeed

[22] Y. Sürmen, Taşıma İşletmeleri Muhasebesi, 1. baskı, Kocaeli, Türkiye:Umuttepe Yayınları, 2015, ss, 672 .

[23] B. Baki, Lojistik Yönetimi ve Lojistik Sektör Analizi, Trabzon, Türkiye: Lega Kitabevi, 2004, ss. 46-54.

[24] F. Yılmaz, "Yüksek hızlı trenlerin bölgesel kalkınmaya etkileri," Yüksek lisans tezi, Fen Bilimleri Enstitüsü, Tokat Gaziosmanpaşa Üniversitesi, Tokat, Türkiye, 2019 .

[25] TMMOB Makina Mühendisleri Odası, "Ulaşımda Demiryolu Gerçeği", Türkiye, Rap. TMMOB: 12, 2012. 
[26] TC Devlet Demiryolları İstatistik Y1llı̆̆g 2008-2012, ISSN 1300-2503, Ankara, 2013.

[27] TC Devlet Demiryolları İstatistik Y1llığı 2007-2011, ISSN 1300-2503, Ankara, 2012.

[28] 2014 Railway safety performance in the European Union, European Railway Agency, France, 2014.

[29] Ulaştırma Bakanlı̆̆ı, 2003-2014 İstatistiklerle Ulaştırma Denizcilik ve Haberleşme, Strateji Geliştirme Başkanlığı, Ankara, s. 11, 2015.

[30] C. Kurt, "Türkiye'de ulaştırma sektörü içerisinde lojistiğin yeri ve önemi," Yüksek lisans tezi, Fen Bilimleri Enstitüsü, İstanbul Üniversitesi, İstanbul, Türkiye, 2010. 